\section{O MUNDO DO TRABALHO BRASILEIRO EM PERSPECTIVA HISTÓRICA}

Jorge L. Alves Natal e César A. Miranda Guedes Departamento de Economia da Universidade Federal de Uberlândia: Revista Economia-Ensaios, v.10, n.2, p.143-69, jul. 1996.

Pesquisas sobre a história da formação social brasileira, notadamente na sua feição mais estritamente econômica, apontam que ao longo de quase um século, mais especificamente, do último quartel do século passado até meados da década de 1970, no âmbito da gênese, desenvolvimento e consolidação do seu padrão nacional de desenvolvimento, ${ }^{1}$ grosso modo, não só aumentou o emprego como a formalização das relações de trabalho. $\mathrm{Na}$ realidade, aquele padrão, que poderia ser sintetizado pelo conceito marxiano de industrialização, contribuiu ainda para que o próprio mercado nacional ${ }^{2}$ se consolidasse. Pari passu, por obra da estratégia geopolítica, especialmente aquela formada no âmbito castrense, mas também pelo próprio processo de constituição do mercado nacional, estabeleceu-se outro cimento importante para a formação da nação brasileira: a chamada integração do território nacional. Esse conjunto de discussões, salvo melhor juízo, nunca sublinhou o papel decisivo do "mundo do trabalho" na construção do mencionado cimento. Melhor dizendo: o aumento do emprego, pelo crescimento econômico quase sustentado ao longo de cem anos e, sobretudo, a generalização também crescente da formalização das relaçôes de trabalho, a partir dos "capitalismos" regionalmente mais avançados, operaram de modo extraordinário para que a noção de território, que já habitava os corações e as mentes dos brasileiros do final do século XIX, se consolidasse entre nós. E, como é amplamente conhecido, para tal foi também decisiva a participação ativa do Estado.

De meados dos anos 70 até o final dos anos 80, adveio a crise econômica, ou, como preferem outros, o esgotamento do antigo padrão de desenvolvimento. Assim, depois de um longo período expansivo, finalmente veio o desemprego, e, com ele, uma nítida inflexão na trajetória de formalização das relaçôes de trabalho. Contudo, não havia ainda se instalado no país a práxis da de-

1 Cf. J. M. Cardoso de Mello, 0 capitalismo tardio. S. Paulo: Brasiliense, 1981. 2 Cf. W. Cano, Desequilibrios regionais e concentração industrial no Brasil: 1930-1970. São Paulo: Global/Unicamp, 1985. monização/negação do Estado, enfim, a política darwinista orientada pelos ditames neoliberais hegemônicos, sublinhando-se aí a exegese da flexibilização das relações contratuais trabalhistas e todo o seu séquito de desregulamentação do mercado de trabalho. De outra maneira: se a crise econômica de meados dos anos 70 iniciou a derrubada dos anteriores níveis de emprego e ampliou a informalização das relaçôes de trabalho, não se pode negar que foi a partir do final dos anos $80 \mathrm{e}$, marcadamente, a partir de 1994, que o próprio poder público filiou-se a uma espécie de novo modelo de (anti)desenvolvimento que não só liquida postos de trabalho como "alimenta" o crescimento da informalização das relações de trabalho, ao valorizar a terceirização, a liquidação de antigos direitos trabalhistas etc.

Não fora o bastante: ao pretender varrer para baixo do tapete a página getulista no que ela tinha exatamente de mais progressista, o atual projeto/estratégia também opera, ao lado de tantas outras determinações, para a destruição crescente de um dos pilares do mercado e da integração nacionais. Explicando melhor: à desconstrução do anterior "mundo do trabalho" brasileiro corresponde, pelo menos em algum grau, a desconstrução do próprio sonho de um território nacional integrado. Lá se vai, ao final do século XX, a noção que os brasileiros do final do século passado haviam fincado em seus coraçôes e mentes.

Porém, mais do que lamentar, é preciso sustar o projeto social daqueles que não aprenderam por formação intelectual, prática política e experiência vivencial a pensar que um país não pode ser resumido à integração competitiva sem fragmentar-se, até mesmo no plano socioespacial (e, desta perspectiva, a chamada crise federativa é uma das manifestações ou qualificação da crise do próprio Estado brasileiro).

$\mathrm{O}$ artigo em pauta, tendo os delineamentos acima como pano de fundo e utilizando dados recentes, examina e defende uma reorientação das discussōes acerca do mundo do trabalho, ressaltando a importância do aspecto territorial, até porque este, ao contrário do que pensam equivocadamente alguns, não constitui mero pano de fundo para as análises de economistas e de intelectuais de outras áreas disciplinares.

Jorge Luiz Alves Natal é doutor em Economia e professor do IPPUR/ UFRJ; César Augusto Miranda Guedes é doutor em Economia e professor do Departamento de Economia da Universidade Federal Rural do Rio de Janeiro. 